RESEARCH ARTICLE

\title{
Investigations on Growth, Biochemical Compounds and Antioxidant activities in Hybrid Maize Genotypes as influenced by Silicon Fertilization
}

\author{
Varsha $^{1}$, Chitdeshwari $^{1 *}$ T, Jegadeeswari ${ }^{1} \mathrm{D}$ and Srinivasan ${ }^{2} \mathrm{~T}$ \\ ${ }^{1}$ Department of Soil Science and Agricultural Chemistry, Tamil Nadu Agricultural University, Coimbatore - 641003 \\ ${ }^{2}$ Department of Millets, Tamil Nadu Agricultural University, Coimbatore - 641003
}

Received : $27^{\text {th }}$ June, 2020

Revised : $20^{\text {th }}$ July, 2020

Accepted : $17^{\text {th }}$ August, 2020

\begin{abstract}
A pot culture study was conducted to investigate the effect of silicon fertilization on the growth and physiological traits of ten different hybrid maize genotypes. The treatment structure comprises three levels of silicon $\left(0,75\right.$ and $\left.150 \mathrm{~kg} \mathrm{ha}^{-1}\right)$ as calcium silicate and ten hybrid maize genotypes in a completely randomized design. The genotypes were imposed with recommended NPK (250:75:75 $\mathrm{kg} \mathrm{ha}^{-1}$ ) and grown-up to 40 days. At the end of 40 days, the dry matter production, SPAD, biochemical compounds like soluble proteins, phenols, proline and antioxidants such as peroxidase and superoxide dismutase (SOD) were recorded. Results showed a linear increase in the overall development of hybrid maize genotypes with increasing silicon fertilization upto $150 \mathrm{~kg} \mathrm{Si} \mathrm{ha}^{-1}$. The genotype $\mathrm{COH}(\mathrm{M}) 8$ was the most responsive genotype to $\mathrm{Si}$ application among all the genotypes, followed by $\mathrm{CMH} 12-586$ and $\mathrm{VaMH}$ 12014. In the case of biochemical attributes, genotypic variation played a significant role in expressing the impact of Si. Lesser response to Si fertilization and its accumulation was noticed with $\mathrm{NK} 6240$ and $\mathrm{COH}$ (M) 9 on the growth and biochemical attributes. Silicon fertilization improved the biochemical and antioxidant activity of the maize genotypes and the response varied with levels of Si. A positive and significant response to Si fertilization was observed with soluble protein (9.82 $\left.\mathrm{mg} \mathrm{g}^{-1}\right)$, phenols $\left(0.70 \mathrm{mg} \mathrm{g}^{-1}\right)$, peroxidase $\left(0.83\right.$ units $\left.\mathrm{min}^{-1} \mathrm{mg}^{-1}\right)$ and SOD activity (8.93 $\mathrm{U} \mathrm{g}^{-1}$ ) whereas an inverse significant relationship was noticed with the proline content $\left(4.43 \mu\right.$ moles $\left.g^{-1}\right)$ of the plants which confirmed the role of $\mathrm{Si}$ in plant defense mechanism. The relationship study also confirmed the positive and significant correlation between growth parameters and dry matter production of the genotypes for silicon fertilization.
\end{abstract}

Keywords: Antioxidants, Biochemical compounds, Chlorophyll, Dry matter production, Maize genotypes, Silicon levels

\section{INTRODUCTION}

Silicon (Si), the second most abundant element on the earth surface, is rapidly gaining attention in agriculture because of its many beneficial effects for plants. Current efforts to resolve this enigma involve comprehensive analyses of the effect of $\mathrm{Si}$ supplementation under various abiotic and biotic stresses. At the same time, research activities are focused on improving Si fertilization and $\mathrm{Si}$ sources for better crop cultivation to understand the involvement of $\mathrm{Si}$ in improving thegrowth and yield of crops (Frew et al., 2018). The ability of Si to alleviate stress is a fundamental component of plant life-processes, and it enhance s biochemical tolerance in plants, which is mainly associated with increased activity of defense-related enzymes, such as poly-phenoloxidase, glucanase, peroxidase, and phenylalanine ammonia-lyase (PAL), production of antimicrobial compounds such as phenolic, flavonoids, phytoalexins and pathogenesis-related proteins in plants besides regulating systemic signals, such as salicylic acid, jasmonic acid, and ethylene (Fortunato et al., 2012; Van et al., 2013). It plays a crucial role in plant growth by conferring mechanical strength to crops and resistance against pathogens and herbivory. Silicon additionally influences plant chlorophyll content and photosynthetic capabilities of crops by improving their light receiving posture (Tubana et al., 2016).

Grasses are well-known high accumulators of $\mathrm{Si}$, and, therefore, serve as an excellent model to study the role of $\mathrm{Si}$ in plant physiology. Maize (Zea mays 
L.) is also known as Si-accumulator grown widely as an important cereal in India. It is known to take up actively and accumulate $\mathrm{Si}$ in its organs (Liang et al., 2007; Coskun et al., 2019) and is highly responsive to Si fertilization (Liu et al., 2011).

Silicon is an agronomically important fertilizer element that enhances plant tolerance to biotic and abiotic stress. It plays a dual role in soil-plant system by reinforcing plant protection measures and by optimizing soil fertility through improved water, physical and chemical soil properties, and maintenance of nutrients in plant-available forms (Meena et al., 2014).The benefits of Si on maize are manifold like improving the population, quality, photosynthetic efficiency, increasing leaf area, yield, etc (Covshoff and Hibberd, 2012). Thus, a short term experiment was carried out with different genotypes of hybrid maize to assess the effectiveness of various levels of silicon applied as calcium silicate on dry matter production and physiological aspects of hybrid maize.

\section{MATERIAL AND METHODS}

\section{Experimental details}

A pot culture study was conducted in the glasshouse of the Department of Soil Science and Agricultural Chemistry, Tamil Nadu Agricultural University, Coimbatore, to know the effect of silicon on growth, biochemical constituents and enzyme activity in ten maize genotypes. The soil chosen for the study was sandy loam in texture having deficient Si content (36.5 $\mathrm{mg} \mathrm{kg}^{-1}$ ) with neutral soil reaction (7.50), non-saline $\left(0.09 \mathrm{dS} \mathrm{m}^{-1}\right)$, non-calcareous and having low organic carbon content $\left(1.18 \mathrm{~g} \mathrm{~kg}^{-1}\right)$. The available $\mathrm{N}\left(86.8 \mathrm{~kg} \mathrm{ha}^{-1}\right)$ and $\mathrm{K}\left(123 \mathrm{~kg} \mathrm{ha}^{-1}\right)$ status were low but high in available $\mathrm{P}\left(23.1 \mathrm{~kg} \mathrm{ha}^{-1}\right)$. Each pot was filled with $4.50 \mathrm{~kg}$ of processed soil and three seeds per pot were sown. The soil test-based basal recommended dose of $\mathrm{N}, \mathrm{P}_{2} \mathrm{O}_{5}$ and $\mathrm{K}_{2} \mathrm{O}$ was applied and the silicon was applied as calcium silicate at three levels 0,75 and $150 \mathrm{~kg} \mathrm{ha}^{-1}$. Ten different hybrid maize genotypes were chosen for the study, out of which eight were TNAU hybrids (CO 6, $\mathrm{COH}(\mathrm{M}) 8, \mathrm{COH}(\mathrm{M}) 9$, VaMH 2014) and cultures (CMH 12-586, CMH 2-686, CMH 14-716, CMH 15005) and two private hybrids (NK 6240 and $900 \mathrm{M}$ Gold). All the plants were grown and harvested at 40 days after sowing for recording SPAD, root volume, and total dry matter production. The biochemical constituents (protein, proline and phenols) and enzyme activities (peroxidase and superoxide dismutase) in the fresh leaves were also analyzed.

Dry matter production: For determining dry matter production, all maize genotypes were harvested, washed with water and separated into shoot and root samples. The samples were then dried in a hot air oven at $70^{\circ} \mathrm{C}$ for $24 \mathrm{~h}$ till they got completely dried following which they were weighed and expressed as $g$ plant ${ }^{-1}$.

SPAD: A chlorophyll meter (SPAD 502) designed by the soil plant analysis development (SPAD 502), Minolta Camera Co. Ltd., Japan, was used to record the chlorophyll index. Measurements were taken on the middle of a fully expanded leaf $\left(3^{\text {rd }}\right.$ or $4^{\text {th }}$ leaf from the apex), and five readings were taken in each replicate to represent the mean chlorophyll index for each treatment.

Root volume: The root volume was measured using water displacement technique by immersing the root in water-filled measuring cylinder. The water displaced is measured using a graduated cylinder and is expressed in $\mathrm{cm}^{3}$.

\section{Biochemical compounds}

Soluble protein: Estimation of soluble protein was carried out using Lowry's method (1951). Two fifty $\mathrm{mg}$ of fresh leaf samples was taken and macerated with $10 \mathrm{~mL}$ of $0.02 \mathrm{M}$ phosphate buffer $(\mathrm{pH} 7.8)$. One $\mathrm{mL}$ of this extract was taken in a test tube, to which $5 \mathrm{~mL}$ of ACT (Alkaline Copper Tartarate) and $0.5 \mathrm{~mL}$ of Folin-Ciocalteau reagent were added. The solution was kept as such for 30 min for color development in the dark at room temperature and the absorbance was measured at $660 \mathrm{~nm}$. Fifty $\mathrm{mg}$ of Bovine serum albumin (BSA) dissolved in a hundred $\mathrm{mL}$ of distilled water (500 ppm) was used as the standard. The soluble protein was calculated and expressed in $\mathrm{mg} \mathrm{g}^{-1}$.

Proline: Proline content of fresh leave samples was analyzed by the method outlined by Bates et al., (1973). About $0.5 \mathrm{~g}$ of leaf sample was macerated with $10 \mathrm{~mL}$ of $3 \%$ sulphosalicyclic acid and centrifuged at 3000 rpm for 10 minutes. From this, 2 $\mathrm{mL}$ of extract was taken in a test tube and added with $2 \mathrm{~mL}$ of acid ninhydrin, $2 \mathrm{~mL}$ of glacial acetic acid and $2 \mathrm{~mL}$ of ortho phosphoric acid. The test tubes were kept in a hot water bath for $1 \mathrm{~h}$ wherein the solution color changes from yellow to red. Then, the solution was transferred to a separating funnel and $4 \mathrm{~mL}$ of toluene was added. The whole mixture was vigorously shaken for 20-30 sec and then allowed to settle. The lower colorless layer was discarded and the upper pink layer was used for measuring the absorbance at $520 \mathrm{~nm}$. The proline content was calculated and expressed as $\mu$ moles $\mathrm{g}^{-1}$ fresh weight.

Total phenols: Estimation of total phenols was carried out as per Bray and Thorpe's method (1954) in which $500 \mathrm{mg}$ of fresh leaf sample was cut into small bits and transferred to test tubes to which 5 $\mathrm{mL}$ of $80 \%$ ethanol was added. The test tubes are heated for 10 mins and cooled off. The leaf samples are macerated with another $5 \mathrm{~mL}$ of $80 \%$ ethanol and centrifuged at $5000 \mathrm{rpm}$ for 10 mins, after 
which the supernatant is collected and the volume is made upto $25 \mathrm{~mL}$. One $\mathrm{mL}$ of supernatant is taken to which $2 \mathrm{~mL}$ of $20 \%$ sodium carbonate $\left(\mathrm{Na}_{2} \mathrm{CO}_{3}\right)$ and $0.5 \mathrm{~mL}$ of Folin's reagent were added. After the development of blue color, absorbance was taken at $660 \mathrm{~nm}$. Standards are prepared using catechol at different concentrations (10, 20.....100 ppm). Total phenols was calculated and expressed in $\mathrm{mg} \mathrm{g}^{-1}$.

\section{Enzyme activities}

Peroxidase: Leaf samples were homogenized using a phosphate buffer of whichone $\mathrm{mL}$ of supernatant was taken and $3 \mathrm{~mL}$ of $0.05 \mathrm{M}$ pyrogallol and $0.5 \mathrm{~mL}$ of $30 \% \mathrm{H}_{2} \mathrm{O}_{2}$ were added. The change in absorbance was measured at $430 \mathrm{~nm}$ for every 30 seconds upto 180 seconds and the enzyme activity was calculated and expressed as Units $\mathrm{min}^{-1} \mathrm{mg}^{-1}$ of sample. (Sadasivamand Manickam, 1992).

Super oxide dismutase: Super-oxide dismutase was estimated by Nitro blue tetrazolium (NBT) method as given by Beau-Champ and Fridovich (1971). Five hundred milligram of leaf sample was macerated using $10 \mathrm{ml}$ HEPES- $\mathrm{KOH}$ buffer containing $0.1 \mathrm{mM}$ EDTA and centrifuged at 15000 rpm for $15 \mathrm{~min}$. The supernatant was collected and made upto $50 \mathrm{~mL}$ volume. One $\mathrm{mL}$ of the enzyme extract was mixed with $3 \mathrm{~mL}$ of the reaction mixture and the absorbance was recorded at $560 \mathrm{~nm}$ after the reaction tubes were illuminated for $15 \mathrm{~min}$. Non-illuminated and illuminated reactions without supernatant were used as controls. One unit of SOD activity was defined as the amount of enzyme required to result in 50\% inhibition of NBT reduction at $560 \mathrm{~nm}$. The result was expressed as units per gram of fresh weight.

\section{Statistical analysis}

The experiment was laid out in a completely randomized design with three replications. The data obtained from the investigations were analyzed using OPSTAT software and were subjected to analysis of variance to find out the significance

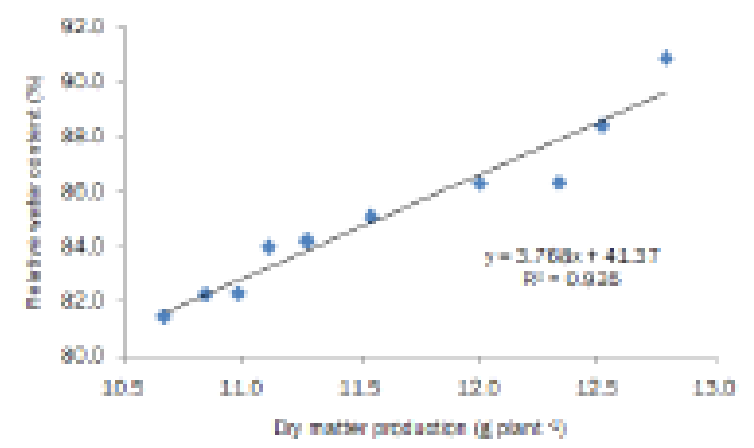

(Panse and Sukhatme, 1978). Wherever the treatment differences were found, significant critical differences (CD) were worked out at 5\% level with a mean separation by the least significant difference and denoted by symbol * , * * for $5 \%$ and $1 \%$, respectively. Non-significant comparisons were indicated as NS. A simple correlation was worked out between different parameters to know the positive or negative relationships between them.

\section{RESULTS AND DISCUSSION}

\section{Dry matter production}

The data on total dry matter production of various maize genotypes were recorded and given in table 1. The application of silicon fertilizers significantly influenced the dry matter production of all the maize hybrids. The highest dry matter production (DMP) of all the maize hybrids was reported with the application of $150 \mathrm{~kg}$ Si ha-1as calcium silicate (13.3 $\left.\mathrm{g} \mathrm{pot}^{-1}\right)$. Among the genotypes, $\mathrm{COH}(\mathrm{M}) 8$ recorded the highest DMP (13.3g pot $\left.{ }^{-1}\right)$ followed by $\mathrm{CMH} 12$ 586 (13.1 pot $^{-1}$ ). The lowest DMP was registered with no silicon applied pots (control) in NK6240 (9.60g pot ${ }^{-1}$ ) and CMH15-005 (9.84g pot ${ }^{-1}$ ). The increased DMP might be due to the beneficial effect of $\mathrm{Si}$, which is known to promote the growth of maize seedlings and eventually contributed to increase in dry matter of maize hybrids, which was also reported by Yang et al. (2008) for its essentiality in plant growth and development. Further, $\mathrm{Si}$ is also known to make the plants to stand erect, which helps in effective utilization of sunlight. This further helped in improved translocation of nutrients, which ultimately increased the dry matter production (Patil, 2017).

An attempt was made to understand the relationship between dry matter production and root volume, which revealed that DMP is positively correlated with root volume $(r=0.973 * *$, Fig. 1$)$. Also, the relationship between DMP with a relative water content of the genotypes were also assessed and found a linear relationship between them as well $(r=0.935 * *$, Fig. 1$)$.

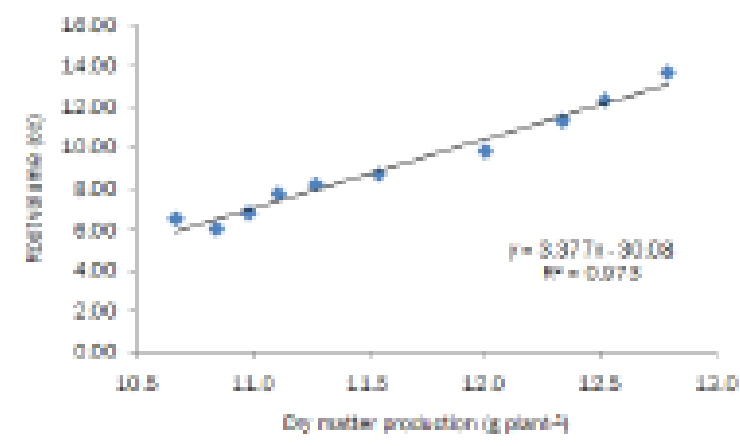

Figure 1. Relationship of dry matter production with relative water content and root volume 


\section{Chlorophyll index}

Chlorophyll content was measured using the SPAD meter for all the maize genotypes, which also increased with increasing levels of Si application. The highest SPAD value was observed in the genotype $\mathrm{COH}(\mathrm{M}) 8$ (40.2) followed by $\mathrm{CMH} 12-586$ (37.6) whereas lesser SPAD values was observed in the genotypes NK6240 (35.0) and CMH5-005 (Table 1). Chlorophylls play an important role not only in the capacity but also in the efficiency of plants' photosynthesis activity. Photosynthetic capacities of crops' applied with Si are improved by the enlarged size of chloroplasts and the increased number of grana in leaves (Xie et al., 2014). SPAD values enhanced with Si fertilization might be due to the fact that Si regulates the stomatal activity and increased the photosynthesis and water use efficiency of plants which eventually resulted in better vegetative growth (Shedeed, 2018). A significant relationship was noticed between DMP and chlorophyll index for all the maize genotypes $(r=0.922 * *)$.

\section{Table 1. Effect of silicon on dry matter production and SPAD of maize genotypes}

\begin{tabular}{|c|c|c|c|c|c|c|c|c|}
\hline \multirow{2}{*}{$\begin{array}{l}\text { Si levels (kg ha- }{ }^{1} \text { ) } \\
\text { Genotypes }\end{array}$} & \multicolumn{4}{|c|}{ Total Dry matter production (g plant ${ }^{-1}$ ) } & \multicolumn{4}{|c|}{ Chlorophyll index } \\
\hline & 0 & 75 & 150 & Mean & 0 & 75 & 150 & Mean \\
\hline $\mathrm{co} 6$ & 10.7 & 11.7 & 12.2 & 11.5 & 32.2 & 34.8 & 36.7 & 34.9 \\
\hline $\mathrm{COH}(\mathrm{M}) 8$ & 12.2 & 12.9 & 13.3 & 12.8 & 36.8 & 38.3 & 40.2 & 38.7 \\
\hline $\mathrm{COH}(\mathrm{M}) 9$ & 10.0 & 11.2 & 11.7 & 11.0 & 30.7 & 34.2 & 36.5 & 34.2 \\
\hline CMH $12-586$ & 11.8 & 12.6 & 13.1 & 12.5 & 34.0 & 35.9 & 37.6 & 36.1 \\
\hline CMH 12-686 & 11.2 & 12.2 & 12.6 & 12.0 & 32.9 & 35.0 & 36.4 & 35.0 \\
\hline СМH 14-716 & 10.4 & 11.5 & 11.9 & 11.3 & 31.0 & 34.0 & 35.6 & 33.8 \\
\hline СMH 15-005 & 9.84 & 11.2 & 11.5 & 10.8 & 31.9 & 34.2 & 36.0 & 34.4 \\
\hline NK 6240 & 9.60 & 11.0 & 11.4 & 10.7 & 30.9 & 33.6 & 35.3 & 33.6 \\
\hline 900 M Gold & 10.2 & 11.3 & 11.8 & 11.1 & 30.5 & 32.9 & 35.0 & 33.1 \\
\hline VaMH 12014 & 11.6 & 12.5 & 13.0 & 12.3 & 33.1 & 35.1 & 37.0 & 35.2 \\
\hline \multirow[t]{2}{*}{ Mean } & 10.8 & 11.8 & 12.3 & 11.6 & 32.4 & 34.8 & 36.6 & 34.9 \\
\hline & $\mathrm{G}$ & $\mathrm{L}$ & G L & & $\mathrm{G}$ & $\mathrm{L}$ & G L & \\
\hline SEd & 0.028 & 0.015 & 0.048 & & 0.315 & 0.172 & 0.545 & \\
\hline $\mathrm{CD}(\mathrm{P}=0.05)$ & 0.055 & 0.030 & 0.096 & & 0.631 & 0.346 & NS & \\
\hline
\end{tabular}

G - Maize genotypes

$$
\mathrm{L} \text { - Levels of silica }
$$

\section{Biochemical constituents}

The effect of silicon fertilization was studied on soluble proteins, proline and phenolic content in the leaves of all the maize genotypes. It was observed that increasing levels of silicon increased the soluble protein and phenol content of the plants but decreased the proline content of the leaves. The highest soluble protein content was measured with
NS - Non significant

the genotype $\mathrm{COH}(\mathrm{M}) 8$, which varied from $8.73 \mathrm{mg}$ $\mathrm{g}^{-1}$ in no silica control to $9.82 \mathrm{mg} \mathrm{g}^{-1}$ in $150 \mathrm{~kg} \mathrm{Si}^{-1}$ $\mathrm{ha}^{-1}$. This was closely followed by $\mathrm{CMH} 12-586$ with $7.84 \mathrm{mg} \mathrm{g}^{-1}$ in control and $8.58 \mathrm{mg} \mathrm{g}^{-1}$ in $150 \mathrm{~kg} \mathrm{Si}^{-1}$ $\mathrm{ha}^{-1}$ (Table 2). This is in good accordance with the findings of Gong (2005), who observed that silicon application prevented oxidation of proteins in wheat and helped in enhancing the protein content of the plant.

Table 2. Effect of different levels of silicon on various biochemical compounds in maize genotypes

\begin{tabular}{|c|c|c|c|c|c|c|c|c|c|c|c|c|}
\hline \multirow{2}{*}{$\begin{array}{c}\text { Si levels (kg ha- }{ }^{1} \text { ) } \\
\text { Genotypes }\end{array}$} & \multicolumn{4}{|c|}{ Soluble protein content $\left(\mathrm{mg} \mathrm{g}^{-1}\right)$} & \multicolumn{4}{|c|}{ Total phenol content $\left(\mathrm{mg} \mathrm{g}^{-1}\right)$} & \multicolumn{4}{|c|}{ Proline $\left(\mu\right.$ moles $\left.g^{-1}\right)$} \\
\hline & 0 & 75 & 150 & Mean & 0 & 75 & 150 & Mean & 0 & 75 & 150 & Mean \\
\hline $\mathrm{CO} 6$ & 6.75 & 7.30 & 7.55 & 7.20 & 0.54 & 0.59 & 0.64 & 0.59 & 9.44 & 7.28 & 4.04 & 6.92 \\
\hline $\mathrm{COH}(\mathrm{M}) 8$ & 8.73 & 9.33 & 9.82 & 9.29 & 0.61 & 0.66 & 0.70 & 0.66 & 9.87 & 7.74 & 4.43 & 7.35 \\
\hline $\mathrm{COH}(\mathrm{M}) 9$ & 7.37 & 7.76 & 7.95 & 7.69 & 0.48 & 0.54 & 0.60 & 0.54 & 9.39 & 7.02 & 2.60 & 6.33 \\
\hline CMH 12-586 & 7.84 & 8.28 & 8.58 & 8.24 & 0.58 & 0.64 & 0.68 & 0.63 & 9.05 & 6.47 & 2.99 & 6.17 \\
\hline CMH 12-686 & 5.85 & 6.14 & 6.36 & 6.12 & 0.43 & 0.50 & 0.54 & 0.49 & 9.26 & 7.17 & 3.66 & 6.70 \\
\hline СMH 14-716 & 5.68 & 5.88 & 6.21 & 5.93 & 0.56 & 0.63 & 0.67 & 0.62 & 8.79 & 6.48 & 3.05 & 6.11 \\
\hline CMH 15-005 & 6.72 & 6.96 & 7.17 & 6.95 & 0.53 & 0.59 & 0.60 & 0.58 & 8.89 & 6.74 & 3.68 & 6.43 \\
\hline NK 6240 & 5.40 & 5.64 & 5.88 & 5.64 & 0.51 & 0.54 & 0.59 & 0.55 & 9.09 & 6.98 & 3.47 & 6.51 \\
\hline 900M Gold & 6.67 & 6.88 & 7.10 & 6.89 & 0.47 & 0.50 & 0.55 & 0.51 & 9.34 & 6.73 & 2.67 & 6.25 \\
\hline VaMH 12014 & 8.36 & 8.60 & 8.85 & 8.60 & 0.50 & 0.62 & 0.65 & 0.59 & 9.65 & 7.13 & 3.88 & 6.89 \\
\hline \multirow[t]{2}{*}{ Mean } & 6.94 & 7.28 & 7.55 & 8.20 & 0.52 & 0.58 & 0.62 & 0.58 & 9.28 & 6.97 & 3.45 & 6.57 \\
\hline & G & $\mathrm{L}$ & G L & & G & L & G L & & $\mathrm{G}$ & L & G L & \\
\hline SEd & 0.051 & 0.028 & 0.089 & & 0.011 & 0.006 & 0.019 & & 0.050 & 0.027 & 0.086 & \\
\hline $\mathrm{CD}(\mathrm{P}=0.05)$ & 0.103 & 0.056 & 0.178 & & 0.022 & 0.012 & NS & & 0.100 & 0.055 & 0.172 & \\
\hline
\end{tabular}

G - Maize genotypes $\quad$ L - Levels of silica

NS - Non significant

$107|7-9| 272$ 
Proline has been considered as a carbon and nitrogen source for rapid recovery from stress and growth, a stabilizer for membranes and a free radical scavenger (Shahnaz et al., 2011). A decrease in levels of proline was observed with an increasing dose of silicon (Table 2). Among the maize genotypes, $\mathrm{COH}(\mathrm{M}) 8$ was observed to contain high proline content in the NPK treatment $\left(9.87 \mu\right.$ moles $\left.\mathrm{g}^{-1}\right)$ followed by VaMH1204 (9.65 $\mu$ moles $\left.\mathrm{g}^{-1}\right)$ and $\mathrm{CO} 6$ $\left(9.44 \mu\right.$ moles $\left.\mathrm{g}^{-1}\right)$. With the application of calcium silicate at $150 \mathrm{~kg} \mathrm{Si} \mathrm{ha}^{-1}$, the proline content was lowered and the lowest content was recorded in

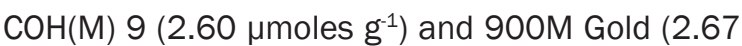
$\mu$ moles $\mathrm{g}^{-1}$ ). Increasing dosage of silicon might have allowed the plants to resist abiotic or biotic stress with the production of silaproline molecules just as in the case of humans. To date, no further studies have been done on this aspect (Kaya et al., 2009).

The total phenol content was observed to increase slightly with the application of silicon (Table 2). Application of silicon at $150 \mathrm{~kg} \mathrm{ha}^{-1}$ increased the phenol content of all maize genotypes and the highest phenol content was found in $\mathrm{COH}(\mathrm{M}) 8(0.70$ $\left.\mathrm{mg} \mathrm{g}^{-1}\right)$ followed by $\mathrm{CMH} 12-586\left(0.68 \mathrm{mg} \mathrm{g}^{-1}\right)$ and VaMH1204 $\left(0.65 \mathrm{mg} \mathrm{g}^{-1}\right)$. The lowest phenol content was observed in NPK control in $\mathrm{CMH} 12-686$ (0.43 $\left.\mathrm{mg} \mathrm{g}^{-1}\right)$ and $900 \mathrm{M}$ Gold $\left(0.47 \mathrm{mg} \mathrm{g}^{-1}\right)$. This is in good corroborations with the works done by Malcovska and his co-workers (2014). Silicon is known to regulate the metabolism and utilization of phenols in plant leaves by producing various Si polyphenol complexes (Shi et al., 2014).

\section{Antioxidant enzymes}

The application of silicon at different levels increased both the peroxidase and the superoxide dismutase activity in hybrid maize regardless of all genotypes (Fig. 3). The highest peroxidase activity was exhibited by $\mathrm{COH}(\mathrm{M}) 8$ in $150 \mathrm{~kg} \mathrm{Si}$ ha-1 treatment $\left(0.83\right.$ units $\left.\mathrm{min}^{-1} \mathrm{mg}^{-1}\right)$ followed by $\mathrm{CMH} 12-586$ (0.74 units $\mathrm{min}^{-1} \mathrm{mg}^{-1}$ ) whereas the lowest activity was recorded in control treatment in $\mathrm{CMH} 14-716$ (0.20 units $\left.\mathrm{min}^{-1} \mathrm{mg}^{-1}\right)$ and NK6240 $\left(0.25\right.$ units $\left.\mathrm{min}^{-1} \mathrm{mg}^{-1}\right)$. Peroxidase has a protective effect also involved in chlorophyll degradation, ROS generation and membrane lipid peroxidation, which are response to injury and a product of senescence (Cao et al., 2015).

As expected, increasing silicon levels increased the superoxide dismutase (SOD) activity in the leaves of maize genotypes and the mean values varied from 5.27 to $8.18 \mathrm{U} \mathrm{g}^{-1}$. The highest value was recorded with the application of $150 \mathrm{~kg} \mathrm{Si}$ ha $^{-1}$ in the genotype $\mathrm{COH}(\mathrm{M}) 8\left(8.93 \mathrm{U} \mathrm{g}^{-1}\right)$. Lesser enzyme activity was observed with $\mathrm{COH}$ (M) 9 (3.82 $\mathrm{U} \mathrm{g}^{-1}$ ) in control treatment (Fig. 3). ). Generation of reactive oxygen species such as superoxide radicals, hydroxyl radicals and hydrogen peroxide causes oxidative damage to plants, but is inevitable in all the aerobic organisms. Plants with high levels of antioxidants, either constitutive or induced, have been reported to have greater resistance to oxidative damage. Plants have evolved specific protective mechanisms, involving antioxidant molecules and enzymes in order to defend themselves against oxidants (Devi et al., 2017). It is evident that silicon is known to influence the anatomical, morphological, biochemical and physiological reactions in the plants under stress by decreasing the permeability as well as the lipid peroxidation of the membrane, thus maintaining membrane stability to the crops as mentioned by Balakhina and Borkowska (2013).
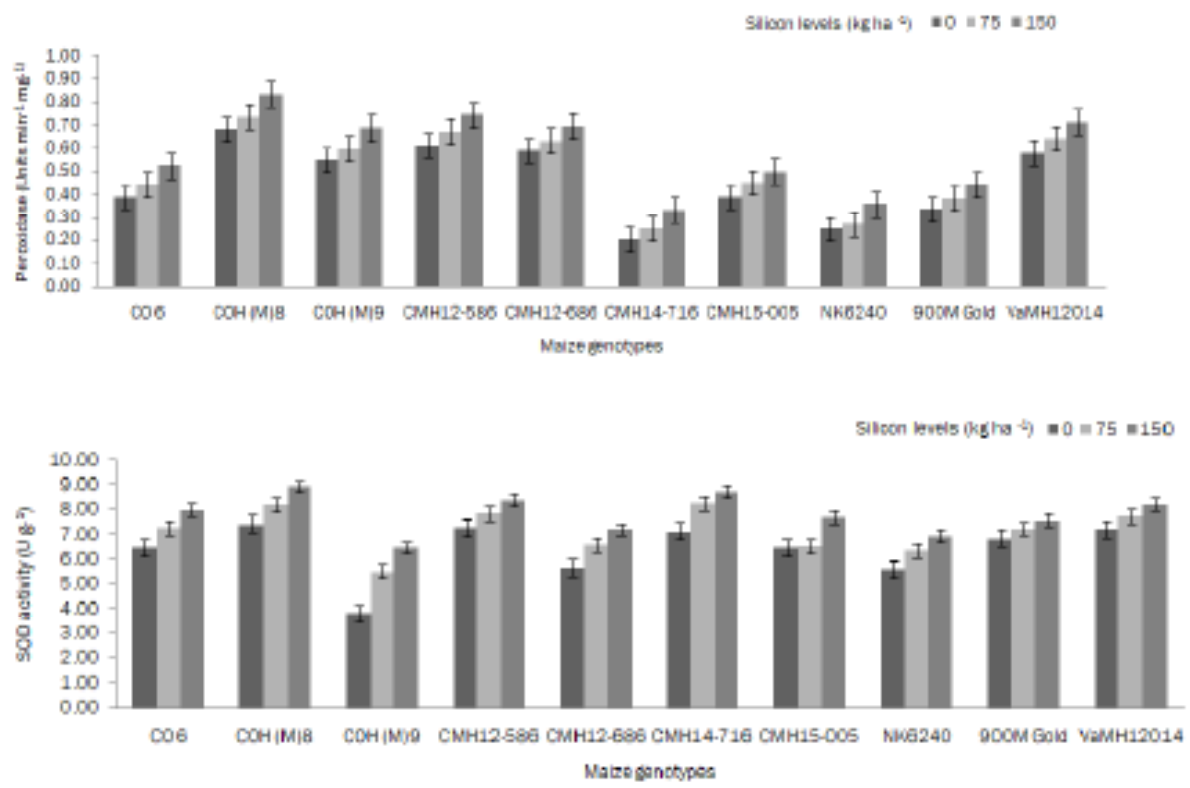

Figure 3. Effect of different levels of silicon on antioxidant enzymes activity in maize genotypes 


\section{CONCLUSION}

This study was a small attempt to know the effect of silicon fertilization on crop growth and their physiological characters. From the results, it is evident that Si does have a role in plant development and growth. Out of all the ten maize genotypes, $\mathrm{COH}$ (M) 8 was found to be Si efficient as it was able to utilize Si better than others to produce more DMP and better growth attributes. Different physiological parameters and their relationship with growth due to silicon fertilization revealed that $\mathrm{Si}$ as calcium silicate improved the growth, physiology and antioxidant enzymes of hybrid maize genotypes. Also, relationship studies between dry matter production and growth attributes like root volume and relative water content showed a linear relationship, which also proved that $\mathrm{Si}$ increases the plant strength, promotes root and shoot growth, improves photosynthetic activity and gives the plants resistance against stress as well. Hence, Si fertilization is not only involved in stress tolerance mechanisms of the plants but also increased the plant establishment and growth.

\section{REFERENCES}

Balakhnina, T. and A. Borkowska. 2013. Effects of silicon on plant resistance to environmental stresses. International Agrophysics, 27 (2): 225 232.

Bates, L. S., Waldren, R. P.\& I. D. Teare. 1973. Rapid determination of free proline for water-stress studies. Plant and Soil, 39(1): 205-207.

Beauchamp, C. \& I. Fridovich. 1971. Superoxide dismutase: improved assays and an assay applicable to acrylamide gels. Analytical Biochemistry, 44(1): 276-287.

Bray, H. G. \& W.V. Thorpe. 1954. Analysis of phenolic compounds of interest in metabolism. Methods of Biochemical Analysis, 27-52.

Cao, B. L., Ma, Q., Zhao, Q., Wang, L. \& K. Xu. 2015. Effects of silicon on absorbed light allocation, antioxidant enzymes and ultrastructure of chloroplasts in tomato leaves under simulated drought stress. ScientiaHorticulturae, 194: 53-62.

Coskun, D., Deshmukh, R., Sonah, H., Menzies, J. G., Reynolds, O., Ma, J. F., Kronzucker, H. J. \& R.R. Bélanger. 2019. The controversies of silicon's role in plant biology. New Phytologist, 221(1): 67-85.

Covshoff, S. \& J.M. Hibberd. 2012. Integrating C4 photosynthesis into C3 crops to increase yield potential. Current Opinion in Biotechnology, 23(2): 209-214

Devi, B. N., Chitdeshwari, T. \& R. Ravikesavan. 2017. Antioxidative enzyme activities in maize genotypes grown under saline water irrigation. Electronic Journal of Plant Breeding, 8(2): 636-642.

Fauteux, F., Chain, F., Belzile, F., Menzies, J. G. \& R. R. Bélanger. 2006. The protective role of silicon in the Arabidopsis-powdery mildew pathosystem. Proceedings of the National Academy of Sciences, 103(46): 17554-17559.

Fortunato, A. A., Rodrigues, F. Á. \& K. J. T. do Nascimento. 2012. Physiological and biochemical aspects of the resistance of banana plants to Fusarium wilt potentiated by silicon. Phytopathology, 102(10): 957-966.

Frew, A., Weston, L. A., Reynolds, O. L. \& G. M. Gurr. 2018. The role of silicon in plant biology: a paradigm shift in research approach. Annals of Botany, 121(7): 1265-1273.

Gong, H., Zhu, X., Chen, K., Wang, S. \& C. Zhang. 2005. Silicon alleviates oxidative damage of wheat plants in pots under drought. Plant Science, 169(2): 313-321.

Kaya, C., Tuna, A. L., Sonmez, O., Ince, F. \& D. Higgs. 2009. Mitigation effects of silicon on maize plants grown at high zinc. Journal of Plant Nutrition, 32(10): 1788-1798.

Liang, Y., Sun, W., Zhu, Y. G. \& P. Christie. 2007. Mechanisms of silicon-mediated alleviation of abiotic stresses in higher plants: a review. Environmental Pollution, 147(2): 422-428.

Liu, J. M., Han, C., Sheng, X. B., Liu, S. K. \& X. Qi. 2011. Potassium-containing silicate fertilizer: its manufacturing technology and agronomic effects. In Oral Presentation at 5th International Conference on Si Agriculature (pp. 13-18)

Lowry, O. H., Rosebrough, N. J., Farr, A. L. \& R. J. Randall. 1951. Protein measurement with the Folin phenol reagent. Journal of Biological Chemistry, 193: 265-275.

Mal ovská, S. M., Du aiová, Z., Masla áková, I. \& M. Ba kor. 2014. Effect of silicon on growth, photosynthesis, oxidative status and phenolic compounds of maize (Zea mays L.) grown in cadmium excess. Water, Air, \& Soil Pollution, 225(8): 2056.

Meena, V. D., Dotaniya, M. L., Coumar, V., Rajendiran, S., Kundu, S. \& A. S. Rao. 2014. A case for silicon fertilization to improve crop yields in tropical soils. Proceedings of the National Academy of Sciences, India Section B: Biological Sciences, 84(3): 505-518.

Panse, V. C. \& P. V.Sukhatme. 1978. Statistical methods for Agricultural workers. III Rev. Ed. ICAR, New Delhi.

Patil, A. A., Durgude, A. G., Pharande, A. L., Kadlag, A. D. \& C. A. Nimbalkar. 2017. Effect of calcium silicate as a silicon source on growth and yield of rice plants. International Journal of Chemical Studies, 5(6): 545-9.

Sadasivam, S. and A. Manickam. 1992. Biochemical methods. 108. Bengaluru: New Age International (P) Limited

Shahnaz, G., Shekoofeh, E., Kourosh, D. \& B. Moohamadbagher. 2011. Interactive effects of silicon and aluminum on the malondialdehyde (MDA), proline, protein and phenolic compounds in Boragoofficinalis L. Journal of Medicinal Plants Research, 5(24): 5818-5827.

Shedeed, S. I. 2018. Assessing effect of potassium silicate consecutive application on forage maize 
plants (Zea mays L.). J. Innovations in Pharma. and Biol. Sci, 5(2): 119-127.

Shi, Y., Zhang, Y., Yao, H., Wu, J., Sun, H. \& H. Gong. 2014. Silicon improves seed germination and alleviates oxidative stress of bud seedlings in tomato under water deficit stress. Plant Physiology and Biochemistry, 78: 27-36.

Tubana, B. S., Babu, T. \& L. E. Datnoff. 2016. A review of silicon in soils and plants and its role in US agriculture: history and future perspectives. Soil Science, 181(9/10): 393-411.

Van Bockhaven, J., De Vleesschauwer, D. \& M. Höfte. 2013. Towards establishing broad-spectrum disease resistance in plants: silicon leads the way. Journal of Experimental Botany, 64(5): 12811293.

Xie, Z., Song, F., Xu, H., Shao, H. \& R. Song. 2014. Effects of silicon on photosynthetic characteristics of maize (Zea mays L.) on alluvial soil. The Scientific World Journal, 2014.

Yang Y., Li J., Shi H., Ke Y., Yuan J. and Z. Tang. 2008. Alleviation of silicon on low-P stressed maize (Zea mays L.) seedlings under hydroponic culture conditions. World Journal of Agricultural Sciences 4: 168-172. 